\title{
Financial Management Importance for Financial Managers in Financial World in the Era of Globalization
}

\author{
Iqbal Shaukat \\ Canadian Association of Postdoctoral Scholars, Toronto, Canada \\ Email address: \\ professionalstudent2020@gmail.com
}

To cite this article:

Iqbal Shaukat. Financial Management Importance for Financial Managers in Financial World in the Era of Globalization. International Journal of Economics, Finance and Management Sciences. Vol. 9, No. 5, 2021, pp. 174-177. doi: 10.11648/j.ijefm.20210905.11

Received: August 1, 2021; Accepted: September 6, 2021; Published: September 27, 2021

\begin{abstract}
In Financial management we cover all the aspects to cover the financial position. The basic purpose is that provide the full information to the management regarding the liquidity position of the Business, with the help of financial management provide the total turnover of the Business operation. Financial management provides the route how to main the good financial position of the Business. The basic function of financial management is to give the path to how to maintain material management. With the help of materiel management we can manage the total equation of material management. The financial management is the basic source of knowledge how to. Maintain the best material management. Just in system is very important in the manufacturing companies, financial management provide the road map how to implement the just in system. Financial management is the key of success for every Business man, who are engage in the financial activities on the massive level. Corporate culture is possible only with financial management. Financial management is the very beneficial for the all section of life.
\end{abstract}

Keywords: Financial, Management, Knowledge

\section{Financial Management Importance Era of Globalization}

Financial management is very important part of our life. With the financial management we can regulate the trade, Business, commerce, finance. When the Business was become modernized, the Business turned over the new leaf. Financial management becomes the regularized when the stock and Business took place. In USA when the wall street and new York stock exchange came in to being the financial management took place. Financial management resolved many problems of financial community. In Banks and financial institutions are taken the very important benefits by financial management. With the help of financial management we calculate the present and future value of the deposits, it help the financial manager where of the investment is stand. Financial management helps the financial managers how to make the portfolio investment, financial management guide the financial manager how to take the benefit from the various combination of investment in stock market. As far as the maximize the profit of the investment financial management provide the guidance regarding the how to use the portfolio investment combination. Portfolio investment is the intrgreal part of the stock market. With the help of portfolio investment there is less chance to reduction in investment. Financial management provides the different techniques of portfolio investment. Risk management is the important part of financial management, with the help of financial management we can evaluate the risks between the two events, in risk management we estimate the type of risk and impact on the financial conditions of the Business. The benefit of the evaluation of risk of investment it creat the easier way to the investors to evaluate the risk. In financial management provide the techniques how to measure the financial risk. During the trade the sweaping process is very important sweap meaning that provide the way how to use the currency of other countries in the different circumstances. Budgeting is the important part of financial management. With the help of Budgeting we project our profit and other part of the Business operation. The capital budget over one years and other master budget which cover to the whole operation of the Business [1-12]. 


\section{Aspects of Financial Management}

Budgeting is the techniques which provide the projection of Business operation. Diversity of investment is very important in the stock market with help of financial management we made the diversity of investment according to circumstances, financial management provide the Way diversity to the investors, in various circumstances diversity of investment is very important, because of this the investors not suffer the loss which can be face through risk. Corporate financing is the basic part of the financial management. In corporate financing get the loan from the financial institutions. Financial management provide the how to get the corporate finance from banking and how can be used for the financial devlopment. Stragtic finance is the importance part of financial management. It helps the enhancement the Business operation through the exchange of benefits, in strategic finance we exchange the benefit which arise by the both parties. for example in strategic financing we have one store outlet you give the permission to other client that he can use his Business outlets. Hedgeing is the importance part of financial management, with the help of that we can cover the loss of transaction which can be suffered in future. Cash flow is the important part of financial management, with the help of financial management we can organize our Business activity. We estimate our financial activities. Material management is the important part of finacial management, with the help of material management we can estimate the financial operation of Business. Dividend is the important of financial management, financial management provide the guidence how to decleard the dividend to the stake holders. Financial management provides the different dividend models, which can be beneficial for the financial managers. Financial management helps the financial manager to help the profitbility of Business operation and the manufacturer concern issue. Like stock in hand. Financial management is the intrgreal part of the Business operation. Financial management helps the financial managers to take decision regarding investment and profitbility.

In Financial management we cover all the aspects to cover the financial position. The basic purpose is that provide the full information to the management regarding the liquity position of the Business, with the help of financial management provide the total turnover of the Business operation. Financial management provides the route how to main the good financial position of the Business. The basic function of financial management is to give the path to how to maintain material management. With the help of materiel management we can manage the total equation of material management. The financial management is the basic source of knowledge how to maintain the best material management. Just in system is very important in the manufacturing companies, financial management provide the road map how to implement the just in system in the manufacturing concern. Financial management provides the way of marketing analysis, with the help of financial management we can analyze the marke situstion very in the long run and in the short run. Financial management helps how to analyze the secureites and shares business. Financial management provide the way to investor, how to invest the money in stock market. The basic function of the financial management to provide the forecast regarding the operation of business. Financial management very important for every country economy. Without financial management we cannot the growth in the corporate sector. The financial management provides the way of corporate culture, corporate culture can be created with the help of financial management. In financial management we creat all step which is very essential for the corporate culture. The basic purpose of corporate culture to minimize the risk. Financial management is very important for the student. Financial management provides the way of knowledge. With the help of financial management student can get knowledge about the stock and securities business. In various countries the financial management is teaching in the various universities. Several professional qualifications are teaching part of world regarding financial management. In this era of globalization the several students of universities and colleges got the certification in the field of financial management. Financial management prove very efficient for the budgeting. Budgeting is the important part of financial management. We can prepare the master budget for the whole business. Master budget is the only tool, which cover all the aspects of the Business management. operation management is the important part of business segament. Financial management provides the models how to implement the best model of operation management. Corporate goverence is very important in this era of globalization. The code of corporate goverence can be implemented with the help of financial management. Financial management helps the measure the financial leverage of the Business. Many type of investment are present in the market for the Business. Financial management provide the total guidence to the holder of securities, how the measure the financial risk and market situations in various circumstances. In this era of globalization many financial product are being introduced after the two thousand. The products are the portfolio investment and Mutul funds. These products are the important part of stock and financial market [2-14].

\section{Implantations of Financial Management in the Financial Market}

In the case of knowledge of financial management we can easily calculate all such product. Return is the important part of part of financial product. Financial management provides the models that how can calculate the return of the product. Financial management provide the course guidence that how to maintain the systematic record of such products multal funds and different type of shares. Corporate finance is the important part of financial management. Corporate finance provides the financial loan 
to corporation in the time of need. Financial management provides the course guidence to the Business man how to settle the terms and conditions with the banks and financial institutes. There are so many aspects of financial management. In this technological era when the population is increasing and demand of the goods are growing, the role of Financial management is very higher compertavily before past years. All the student of the Finance and accounting should get the solid knowledge of financial management. With the help of financial management we can get the job in the taff job market where the competition is very high. Financial management is only way which provide the destination of economic development [3-16].

\section{Link Between the Managerial Accounting and Financial Management}

Link between the managerial accounting and financial management is very important. Most segament of managerial accounting is derived from financial management. Managerial Accounting is the important part of the knowledge of Accountancy. After the modernization of era the managerial accounting become more effective. The purpose of Managerial Accounting is to creating the good management information system. Managerial Accounting is very effective in the manufacturer sector. Managerial Accountancy is very efficient for the industrial sector. Managerial Accountancy analyzes the financial efficiency of business. Managerial Accounting provides the better information to management regarding manufacturing operation. In managerial accounting we can estimate the break even analysis in which the company covered the fixed cost of Business. This the right estimate how the company can face the loss. Segementation reporting is the important part of managerial accounting. In segment report we estimate the fixed and verible cost of the segment of the Business. Material cost is the important part of Business, in managerial accounting we estimate the material cost from various angles, we estimate the best material models, which is suitable for the Business inventory. Budgeting is the important part of the managerial finance. Budgeting predict the whole operation cost of the Manufacturing cycle. With the help of managerial accounting we can make the incremental budget, Master budget, Annual budget. managerial accounting to estimate the trade cycle, how the ups and down come in business. Managerial Accountancy provides the how the payroll system of business, with the help of payroll system we can better estimate the labour cost and bonus plans. With the help of Managerial Accounting we can handle the manufacturer system with the help of journalization of entries. We can maintain the accounting record between the factory and head office. Managerial Accountancy system is one tool of provides the opportunity of better operation of business. Managerial Accounting provides the strong environment in which all the operation of business runs efficiently. Managerial Accountancy is very important regarding the operation and production management. Management Accountancy help the maximize the resources of the Business and minimize the cost of Business. If we want the good Business management we should adopt the managerial accounting stance. We should hire such type of expert of managerial who work with the stance and efficiently according to the requirement of managerial Accounting [3-10].

\section{Globalize Aspect of Financial Management}

Financial management increases the scope of management studies. Financial management is vital for the professional who are in the various sectors like construction, engeering and other professionals. In these days financial management studies are conducted by various institutes. In these days students are doing the financial management course on the massive level. In these days the financial management qualifications on the Masters levels and on the $\mathrm{PhD}$ level. Many research papers are written by the $\mathrm{PhD}$ holders and researches on financial management important. Many $\mathrm{PhD}$ thesis researches are available on the Google citations. when we review the financial management constants we will find that various solids topics. In the Financial management we study the resources management in which we study how to utilize the resources which are available on the ground land, capital, entrepreneur ship. In the course of financial management we review the buying and selling material. During the study of financial management how the material is being utilized the material for the construction and other purposes, in the financial management we use the different model how the usages of material is calculated. In the financial management we can calculate the wages rates of labours, with the help of certain formula we can easily calculate wages rates system. In the financial management system we can easily maintain the system of layout system. With the help of layout system we can estimate the how the cost is minimize. In layout system we can find the location where the equipment is easily available to the sites. Financial management system reduces the cost of material and labour cost.

\section{Conclusion}

Financial management is the important part of human life. Financial management provides the way of development in this era of globalization. If one person wants good future, He should have the sound knowledge of financial management. In the era of globalization the financial management is very important for financial managers and financial Analyst. Financial management is important for the cost accountant and financial accountant. Many financial analysts perform with the true spirite of financial management. 


\section{References}

[1] Staff, Investopedia (2003-11-20). "Finance". Investopedia. Retrieved 2018-11-26.

[2] "Finance" Farlex Financial Dictionary. 2012.

[3] Melicher, Ronald and Welshans, Merle (1988). Finance: Introduction to Markets, Institutions \& Management (7th ed.). Cincinnatti OBN: Southwestern Publishing Company. p. 2. ISBN 0-538-06160-X.

[4] Irons, Robert (July 2019). The Fundamental Principles of Finance. Google Books: Routledge. ISBN 9781000024357. Retrieved 3 April 2021.

[5] Fergusson, Nial. The Ascent of Money. United States: Penguin Books.

[6] "Herodotus on Lydia". World History Encyclopedia. Retrieved 2021-05-13.

[7] "babylon-coins.com". babylon-coins.com. Retrieved 2021-0513.
[8] Bank of Finland. "Financial system".

[9] "Introducing the Financial System | Boundless Economics". courses.lumenlearning.com. Retrieved 2020-05-18.

[10] "What is the financial system?" Economy.

[11] "Personal Finance - Definition, Overview, Guide to Financial Planning". Corporate Finance Institute. Retrieved 2019-10-23.

[12] Publishing, Speedy (2015-05-25). Finance (Speedy Study Guides). Speedy Publishing LLC. ISBN 978-1-68185-667-4.

[13] "Personal Finance - Definition, Overview, Guide to Financial Planning". Corporate Finance Institute. Retrieved 2020-05-18.

[14] Snowdon, Michael, ed. (2019), "Financial Planning Standards Board", Financial Planning Competency Handbook, John Wiley \& Sons, Ltd, pp. 709-735, doi: 10.1002/9781119642497.ch80, ISBN 9781119642497.

[15] Kenton, Will. "Personal Finance". Investopedia. Retrieved 2020-01-20.

[16] Doss, Daniel; Sumrall, William; Jones, Don (2012). Strategic Finance for Criminal Justice Organizations (1st ed.). Boca Raton, Florida: CRC Press. p. 23. ISBN 978-1439892237. 